\title{
Effect of Organic, Inorganic and Bio-fertilization on Growth, Yield and Quality Traits of Some Chickpea (Cicer arietinum L.) Varieties
}

\author{
Mahmoud Fathy Seleiman and Mohammed Sayed Abdelaal ${ }^{\#}$ \\ Department of Crop Science, Faculty of Agriculture, Menoufia University, Shibin El- \\ koom, Egypt.
}

T

WO FIELD experiments were carried out during 2015/2016 and 2016/2017 seasons, in the Experimental Farm, Faculty of Agriculture, Menoufia University, Shebin El-Koom, Egypt, to study the effect of six fertilization treatments, i.e., no fertilizer as a control $\left(\mathrm{F}_{1}\right)$, macro elements $\left(\mathrm{F}_{2}\right)$, micro elements $\left(\mathrm{F}_{3}\right)$, biofertilizer $\left(\mathrm{F}_{4}\right)$, organic fertilizer $\left(\mathrm{F}_{5}\right)$ and combination of macro and micro elements as well as bio and organic fertilizer treatments $\left(\mathrm{F}_{6}\right)$ on growth characters, yield and yield components and seed quality of two chickpea (Cicer arietinum L.) cultivars, i.e., Giza 3 and Giza 195. The results could be summarized as follows:

1- Giza 195 cultivar significantly exceeded Giza 3 cultivar in growth characters (number of branches and leaf area/plant as well as leaves, stem and total dry weight/plant ). The application of $\mathrm{F}_{6}$ treatment exhibited the highest significant values of plant height and leaf area/plant as well as leaves, stem and total dry weight/plant. However, the maximum significant values of number of branches/plant were recorded when chickpea plants were treated with $\mathrm{F}_{4}$. The interaction treatment of Giza 195 cultivar fertilized with $\mathrm{F}_{6}$ treatment produced the highest values of leaves and total dry weight/plant

2- Giza 195 cultivar significantly surpassed Giza 3 cultivar in seed weight/plant and its components ( no. of pods/plant, no. of seeds/pod, 100-seed weight and seed weight/pod), yields/ha (seed, straw and biological) and translocation indices (crop and harvest indices). The application of $\mathrm{F}_{4}$ treatment was most effective for increasing seed weight/plant and its components as well as seed, straw and biological yields/ha. Giza 195 cultivar fertilized with $\mathrm{F}_{4}$ treatment is considered the best interaction treatment for producing the highest values of no. of pods and seed weight/plant as well as seed and biological yields/ha in both seasons.

3- Giza 195 cultivar showed better performance and exceeded Giza 3 cultivar in seed quality (total nitrogen, total crude protein and carbohydrate percentages), while, Giza 3 cultivar was superior in fiber and ash percentages. The application of $\mathrm{F}_{4}$ treatment produced the highest values of seed quality (total nitrogen, total crude protein and carbohydrate percentages), while, the highest values of fiber and ash percentages were obtained by the application of $\mathrm{F}_{5}$ treatment as compared with the other tested fertilizer treatments.

Keywords: Productivity, Quality, Bio-fertilizer, Organic and Inorganic fertilizer, Chickpea.

\section{Introduction}

Chickpea (Cicer arietinum L.) is one of winter legumes that can be widely used as food, where it demand in human diet is mostly due to fairly low price and balanced seed nutrients composition and it is a rich source of protein, i.e., $15.7-28.0 \%$ (Wang et al., 2017), carbohydrate, fat, minerals (P, K, Ca, Mg, Fe and $\mathrm{Zn}$ ), amino acids except Sulphur-containing amino acids and $\beta$-carotene (Jukanti et al., 2012). Chickpea is globally grown on about $14.4 \mathrm{M}$ ha with a production of 14.2
Mt seeds during 2014 in over than 50 countries (FAOSTAT, 2014). In Egypt, the cultivated area of chickpea was 8440,4563 and 623 ha which produced 15315, 9527 and 1323 ton during 2000, 2007 and 2014, respectively (FAOSTAT, 2014).

Chickpea productivity can be increased through high productive cultivars with the application of the optimal agricultural practices. The method, form and type of the applied fertilizers are considered the most limiting factors for yield and seed quality of chickpea. Nutrients

"Corresponding author email: moha3b3al@gmail.com

DOI: 10.21608/agro.2018.2869.1093

C2018 National Information and Documsentation Centre (NIDOC) 
application can be added via foliar sprays and/or land application. Foliar application of nutrition is used to reduce the problems of immobilization and leaching of different nutrients.

Macronutrients, in particular nitrogen $(\mathrm{N})$, phosphorus $(\mathrm{P})$ and potassium $(\mathrm{K})$ are essential and important nutrients for plant growth and its development (Erman et al., 2011). However, adding such macronutrients to plants through chemical fertilizers is costly and the excessive use of chemical fertilizers can pose environmental problems which can cause potential risk for sustainability of agricultural systems (Vance, 1997). Moreover, micronutrients can enhance growth and improve yields of plant species, if they applied at appreciated stages and in optimal doses. Boron (B) is an important micronutrient that can play an important role in reproductive plant parts, cell division, stomatal regulation, seed formation, carbohydrate utilization. Also, Fe is needed for biological redox system and enzyme activation (Marschner, 1995). It plays very important role in many metabolic processes for instance DNA synthesis and photosynthesis (Rout \& Sahoo, 2015). The process initiation of chlorosis could be attributable to the deficiency of Fe interfaces with some other micronutrients such as Mn and Zn (Dixit \& Yamdagni, 1983). Furthermore, Mn is very important for enzyme activation, electron transport and disease resistance (Burnell, 1988). However, Mn can be reduced under Fe deficiency conditions in plant roots and shoots, since Mn can be transported from soil solution into plant via $\mathrm{Fe}$ transporters (López-Millán et al., 2004).

Bio-fertilizers can lessen the required chemical fertilizers and the adverse environmental effects in terms of easing the environmental contamination and worsening of nature (Namvar et al., 2011). On the other hand, organic fertilizers have been utilized in agriculture system in latest years. Humic acid is used as organic fertilizers and it contains important nutrients particularly $\mathrm{K}$. Humic acid can be used to lessen the adverse effect of salt stress. Soil application of $1.0 \mathrm{~kg}$ humic acid ha ${ }^{-1}$ can result in an increase in yields around $20 \%$ of maize (Zea mays L.) and enhanced the physical and chemical traits of soil (Sharif et al., 2003). Combination of humic acid with chemical fertilizers has also shown an improvement for growth and yield of cowpea (Vigna unguiculata L.) in comparison to individual application of chemical, organic or bio-fertilizers (Magdi et al., 2011).
Therefore, the aims of the current study were to investigate the response of growth, yield and quality of two chickpea for mineral, organic and bio-fertilizers and their combination.

\section{Materials and Methods}

Two field experiments were conducted in experimental farm, Faculty of Agriculture, Menoufia University, Shebin El-koom, Egypt (Latitude: $30^{\circ} 33^{\prime} 31^{\prime \prime}$ and Longitude: $31^{\circ} 00^{\prime}$ 36 ") during 2015/2016 and 2016/2017 seasons to investigate growth, yield and seed quality of two chickpea (Cicer areitinum L.) cultivars as affected by six fertilization treatments. The two tested cultivars, namely Giza 3 and Giza 195, were obtained from Agriculture Research Centre, Ministry of Agriculture, Egypt. The six fertilization treatments comprised $\mathrm{F}_{1}$ : No fertilizer as a control, $\mathrm{F}_{2}$ : Macro elements, $\mathrm{F}_{3}$ : Micro elements, $\mathrm{F}_{4}$ : Bio- fertilizer, $\mathrm{F}_{5}$ : Organic fertilizer and $\mathrm{F}_{6}$ : Combination fertilizer. The design of each experiment was a split plot design with three replications where the two cultivars were placed in main plots, while the six fertilization treatments were arranged in sub-plots. $\mathrm{F}_{2}$ treatment included nitrogen $(\mathrm{N})$, phosphate $(\mathrm{P})$ and potassium $(\mathrm{K})$ which were soil applied at a rate of $35 \mathrm{~kg} \mathrm{~N} / \mathrm{ha}$ as urea $(46.5 \% \mathrm{~N})$, $55 \mathrm{~kg} \mathrm{P}_{2} \mathrm{O}_{5} /$ ha as calcium super phosphate $(15.5$ $\% \mathrm{P}_{2} \mathrm{O}_{5}$ ) and $55 \mathrm{~kg} \mathrm{~K}_{2} \mathrm{O} /$ ha as potassium sulphate $\left(48 \% \mathrm{~K}_{2} \mathrm{O}\right) . \mathrm{F}_{3}$ treatment was foliar applied at a rate of $2 \mathrm{~L} /$ ha using commercial compound namely MC quality (Valagro Company, Italy) included ferric (Fe $0.8 \%$ chelated with DTPA), manganese (Mn 0.4\% chelated with EDTA) and boron (B $0.8 \%) . \mathrm{F}_{4}$ treatment was soil added at a rate of $12 \mathrm{~L} /$ ha using commercial compound namely TS (Bio Tech company, Sadat City, Egypt) included Bacillus polymxa, Bacillus megatherium, Bacillus circulans, Yeast (Candida spp.) and Trichoderma spp. $\mathrm{F}_{5}$ treatment was foliar applied at a rate of $2 \mathrm{~kg} /$ ha using humic acid included potassium humate crystals, $10 \%$ $\mathrm{K}_{2} \mathrm{O}$, (mediterranea de agroquimicos, Barcelona, Spain). $\mathrm{F}_{6}$ treatment $\left(\mathrm{F}_{2}+\mathrm{F}_{3}+\mathrm{F}_{4}+\mathrm{F}_{5}\right)$ was added at the same rate and method application of each abovementioned treatments. All tested fertilizer treatments were splitted to two equal doses at 35 and 55 days after sowing (DAS). Soil samples before sowing in both seasons were collected for mechanical and chemical analysis as described by Jackson (1973) and Chapman \& Pratt (1978). Mechanical and chemical analysis of soil is presented in Table 1. 
TABLE 1. Mechanical and chemical properties of the experimental soil during 2015/2016 and 2016/2017 seasons.

\begin{tabular}{|c|c|c|c|c|c|c|c|c|c|c|}
\hline \multirow{2}{*}{ Proper } & \multicolumn{4}{|c|}{ Mechanical properties } & \multicolumn{6}{|c|}{ Chemical properties } \\
\hline & $\begin{array}{c}\text { Sand } \\
\%\end{array}$ & $\begin{array}{l}\text { Silt } \\
\%\end{array}$ & $\begin{array}{c}\text { Clay } \\
\%\end{array}$ & Soil texture & $\begin{array}{c}\text { Ec } \\
(\mathrm{Ds} / \mathrm{m})\end{array}$ & pH & O.M (\%) & $\mathbf{N}$ & $\mathbf{P}$ & $\mathbf{K}$ \\
\hline $2016 / 2017$ & 21.35 & 41.82 & 36.83 & Clay loam & 0.74 & 7.3 & 1.82 & 26.78 & 8.98 & 286.47 \\
\hline
\end{tabular}

The area of each sub-plot was $12 \mathrm{~m}^{2}$ (4 m length $\times 3 \mathrm{~m}$ width) and it consisted of five lines with 60 $\mathrm{cm}$ a part. The preceding crops were maize (Zea mays L.) and sunflower (Helianthus annuus L.) in the first and second seasons, respectively. Seeds were sown at a rate of $100 \mathrm{~kg}$ seeds ha-1 in hills (15 $\mathrm{cm}$ between each two hills) on $7^{\text {st }}$ December 2015 and on $20^{\text {th }}$ November 2016. Seeds were sown on two ridges of each line. After three weeks from sowing, chickpea plants were thinned to one plant hill $^{-1}$. Mechanical control for weeds was used. All recommended agricultural practices were done according to the rules of Ministry of Agriculture, Egypt.

\section{Measurements studied}

Growth characters

At beginning of flowering stage (75 DAS), five plants from each sub-plot were randomly taken to measure plant height $(\mathrm{cm})$, number of branches plant ${ }^{-1}$ (primary and secondary), leaves area plant ${ }^{-1}\left(\mathrm{~cm}^{2}\right)$, leaves, stems and total plant dry weight plant $^{-1}(\mathrm{~g})$.

\section{Yield and yield components}

At harvest, $5^{\text {th }}$ May 2016 and 26 th $^{\text {th }}$ May 2017, ten plants were randomly collected from the middle ridges of each sub-plot for measuring number of pods plant ${ }^{-1}$, number of seeds pod ${ }^{-1}$, seed index (100-seed weight, g), weight of seeds $\operatorname{pod}^{-1}(\mathrm{~g})$ and seed weight plant ${ }^{-1}(\mathrm{~g})$. Seed, straw and biological yields per ha were measured by harvesting plants of the two middle lines (each $3 \mathrm{~m}$ long) at ground level from each sub-plot. Plants were air-dried under shade until constant weight. Translocation indices (crop and harvest indices) were calculated as follows:

Harvest index $=\left(\right.$ Seed yield $\mathrm{ha}^{-1} \div$ Biological yield ha $\left.{ }^{-1}\right) \times 100$

Crop index $=\left(\right.$ Seed yield ha ${ }^{-1} \div$ Straw yield ha- $)$ $\times 100$

\footnotetext{
Seed quality

Chickpea seeds $(\sim 15 \mathrm{~g})$ were milled into
}

a fine powder using a UDY cyclone mill (Udy Corporation, Colorado, USA), and the powder was then passed through a $0.5 \mathrm{~mm}$ sieve. Finally, the powder was used in the analysis of total nitrogen, crude protein, carbohydrate, fibre and ash percentages. The total carbohydrate $\%$ was analyzed using method described by A.O.A.C (2000). Total nitrogen content was analyzed using micro-Kjeldahl method (Tecator, 1991). Total crude protein \% was calculated by multiplying total $\mathrm{N} \% \times 6.25$. Crude fibre $\%$ was analyzed using modified Weende method described by Van Soest \& McQueen (1973). Ash \% was estimated using samples of $5 \mathrm{~g}$ from milled seeds which were oven-dried at $+105^{\circ} \mathrm{C}$ for $12 \mathrm{~h}$ and weighed for $\mathrm{W} 1$, and immediately were placed into a muffle furnace at $+600^{\circ} \mathrm{C}$ for $18 \mathrm{~h}$. Then, the samples were moved, cooled in a desiccator for $30 \mathrm{~min}$ and weighed (W2). The ash \% was calculated as follows:

$$
\text { Ash } \%=\frac{\mathrm{W} 2}{\mathrm{~W} 1} \times 100
$$

\section{Statistical analysis}

Data obtained of growth, yield and quality traits were subjected to analysis of variance (ANOVA) using PASW statistics 21.0 (IBM Inc., Chicago, IL, United States of America). Least Significant Difference (LSD at $\mathrm{p} \leq 0.05$ ) was used to compare the differences between mean of treatments.

\section{Results and Discussion}

\section{Growth characters}

\section{Varietal differences}

The data in Table 2 included the mean performance of the two chickpea cultivars (Giza 3 and Giza 195) for their growth characters , i.e., plant height, number of branches and leaves area/plant as well as leaves, stem and total dry weight/plant (at beginning of flower stage) during 2015/2016 and 2016/2017 seasons. 


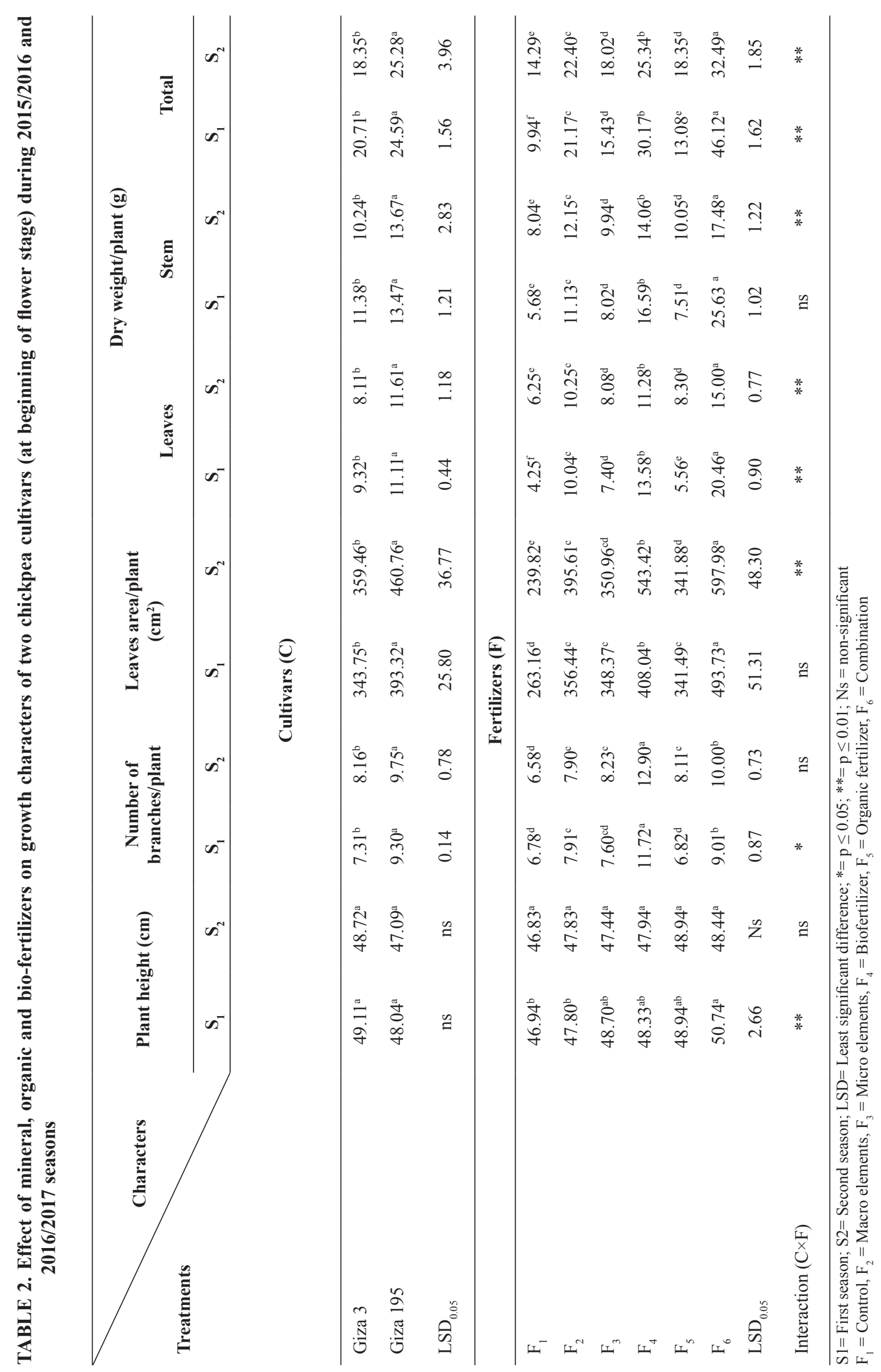

Egypt. J. Agron. 40, No. 1 (2018) 
The data show that no significant variations was observed in respect of plant height between the two tested cultivars in both seasons. However, there was significant differences between the two tested cultivars in the rest growth characters studied in favor of Giza 195 cultivar in both seasons. Moreover, it can be noticed that Giza 195 cultivar surpassed Giza 3 cultivar by 23.35 , 21.30, 31.18, 25.93 and $28.24 \%$ in number of branches, leaves area and dry weight of leaves, stem and total, respectively, as an average of the two seasons. The differences between the two tested cultivars in their performance for growth characters may be attributed to their genetic background which played the major role in this respect. The varietal differences among some chickpea varieties in their growth characters, i.e., plant height, no. of branches/plant, dry weight of leaves and total plant were previously detected by Ahmed et al. (2010), El-Habbasha et al. (2012) and Ahmed et al. (2015).

\section{Effect of fertilizers}

Data presented in Table 2 declared that all growth characters studied at beginning of flower stage were significantly affected by the tested fertilizers treatments, i.e., no fertilizer as a control $\left(\mathrm{F}_{1}\right)$, macro elements $\left(\mathrm{F}_{2}\right)$, micro elements $\left(\mathrm{F}_{3}\right)$, biofertilizer $\left(\mathrm{F}_{4}\right)$, organic fertilizer $\left(\mathrm{F}_{5}\right)$ and the combination of macro and micro elements as well as bio and organic fertilizer treatments $\left(\mathrm{F}_{6}\right)$ in both seasons with exception of plant height in the second season. The application of $\mathrm{F}_{6}$ treatment produced the highest significant values of most growth characters studied followed by $\mathrm{F}_{4}, \mathrm{~F}_{2}, \mathrm{~F}_{5}$ and $F_{1}$ treatments in a descending order, as an average of the two seasons. The magnitude of increase in plant height and leaf area/plant as well as leaves, stem and total dry weight/plant obtained by the application of $\mathrm{F}_{6}$ treatment amounted to $5.77 \%, 118.48 \%, 260.70 \%, 234.32 \%$ and $245.67 \%$, respectively more than that obtained by $F_{1}$ (no fertilizer). On the other hand, the greatest number of branches/plant were obtained when the plants were treated with biofertilizer $\left(\mathrm{F}_{4}\right)$ which produced an increase percentage amounted to $84.45 \%$ more than the unfertilized plants $\left(\mathrm{F}_{1}\right)$, as an average of both seasons. The superiority of growth characters for chickpea plants treated with the combination treatment $\left(\mathrm{F}_{6}\right)$ may be due to that such treatment included some essential macro elements ( $\mathrm{N}, \mathrm{P}$ and $\mathrm{K}$ ), micro elements (Fe, $\mathrm{Mn}$ and B), biofertilizers (some beneficial bacteria ,i.e., nitrogen fixing bacteria "NFB", phosphate solubilizing bacteria "PSB" and potassium mobilizing bacteria "KMB" as well as some benefical fungus, i.e., yeast and Trichoderma) and organic fertilizer (humic acid). All those components jointly consists of many stimulants substances and/or sources of promoter hormones which had positive and beneficial effects on improving the vegetative growth of plant. In this concern, other investigators found increment and enhancement in some growth characters of chickpea plants due to the application of macro elements, i.e., N, P and K (Goud et al., 2014 and Shah et al., 2016), micro elements, i.e., mixture of Fe, Mn, B, Zn , Cu and Mo (El-Habbasha et al., 2012) and biofertilizers included PSB (Dutta \& Bandyopadhyay, 2009) as well as NFB and yeast fungi (Ahmed et al., 2010).

Effect of the interaction between cultivars and fertilizers

The interaction effect between the two tested factors, i.e., varieties and fertilizers was statistically significant on leaves and total plant dry weight in both seasons is shown graphically in Fig 1. However, there are no significant effect between the two tested factors on the rest growth characters studied in the first and/or second seasons. The data illustrated in Fig. 1 show that the two chickpea differed in their response to various fertilizer treatment. Giza 195 and Giza 3 cultivars produced their maximum values of leaves dry weight/plant (18.45 and $17.01 \mathrm{~g}$ ) and total dry weight/plant (40.95 and $37.66 \mathrm{~g}$ ) when they were treated with the combination treatment $\left(\mathrm{F}_{6}\right)$, as an average of both seasons. However, the lowest values of the same respective cultivars amounted to 6.27 and $4.23 \mathrm{~g}$ for leaves dry weight/plant as well as 14.23 and $10.00 \mathrm{~g}$ for total dry weight/ plant when they were untreated with any tested fertilizer (control treatment $\mathrm{F}_{1}$ ), as an average of the two seasons.

\section{Yield and yield components \\ Varietal differences}

Data in Tables 3 and 4 show that significant variation was observed between the two tested cultivars in seed weight/plant and its components (number of pods/plant, 100-seed weight, and seed weight/pod) and seed, straw and biological yields/fad as well as translocation indices (crop and harvest indices) in both seasons. However, the number of seeds/pod was not significantly affected by the tested cultivars in the two seasons. Moreover, it can be noticed that Giza 195 cultivar showed better performance and was exceeded by $94.80 \%$ for number of pods/plant, $30.60 \%$ for 
100 -seed weight, $34.36 \%$ for seed weight/pod, $142.53 \%$ for seed weight/plant, $121.64 \%$ for seed yield/ha , 58.98\% for straw yield/ha and $73.45 \%$ for biological yield/ha more than Giza 3 cultivar, as an average of the two growing seasons. The superiority of Giza 195 cultivar in each of seed, straw and biological yields/ha is logical owing to the clear increase in their values of most growth characters studied as previously discussed in Table 2 as well as seed weight/plant and most of its components as previously noticed in Table 3 . In addition, the data show also that Giza 195 cultivar had the highest significant values of translocation indices, i.e., crop index (41.92\%) and harvest index $(29.53 \%)$ as compared with that obtained by Giza 3 cultivar, as an average of both seasons. This means that the highest yielding variety (Giza 195) had potentiality to transport great amount of metabolites synthesized from the vegetative organs to the developing seeds more than that in the other tested variety (Giza 3). In this concern, other researchers found variation among some chickpea varieties in 100- seed weight and seed weight/plant (Aliu et al., 2016) as well as no. of pods/plant and no. of seeds/pod (Alam et al., 2017).

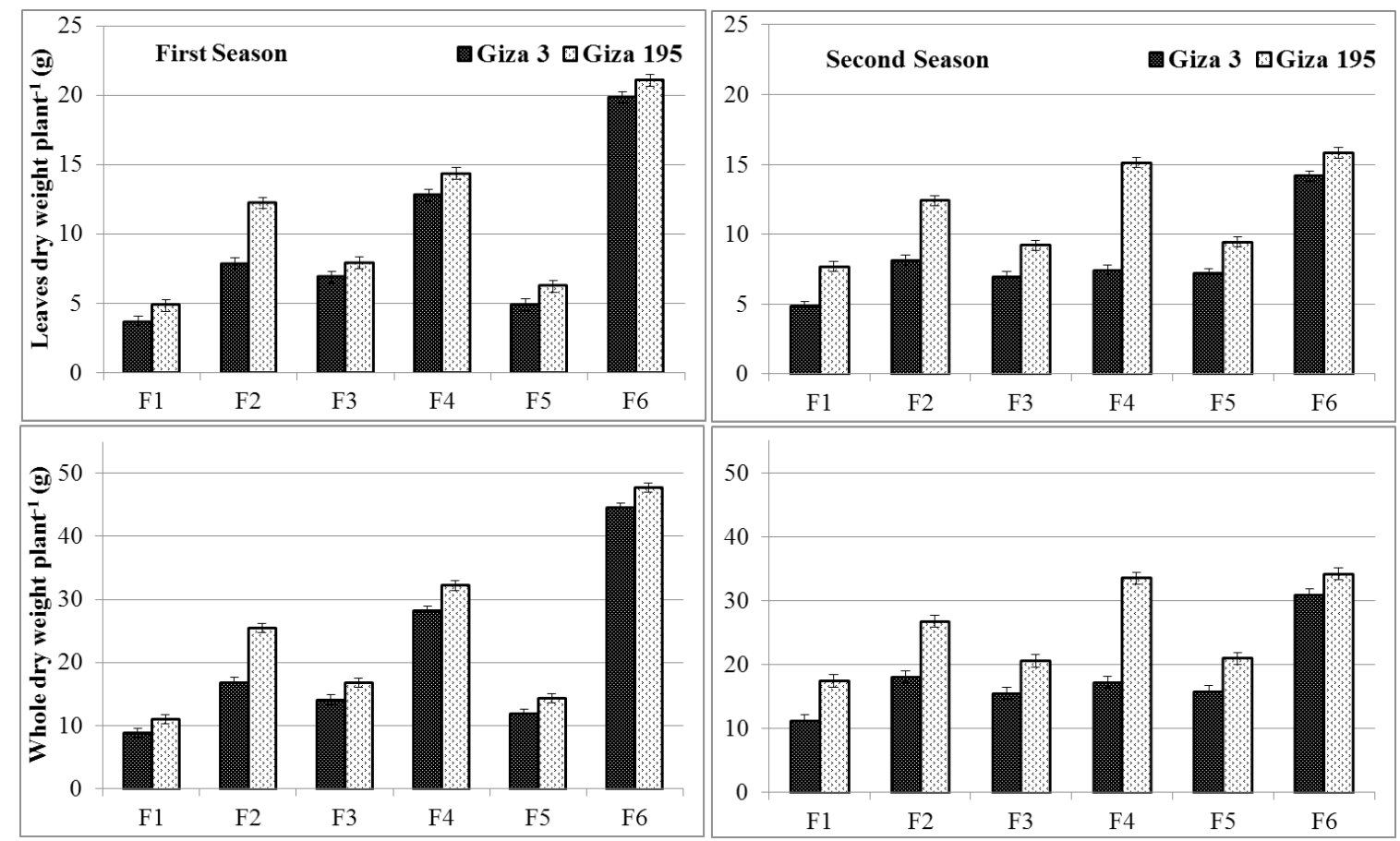

Fig. 1. Effect of the interaction between chickpea cultivars and fertilizer treatments on dry weight of leaves and whole plant during 2015/2016 and 2016/2017 seasons.

$F_{1}=$ Control, $F_{2}=$ Macro elements, $F_{3}=$ Micro elements, $F_{4}=$ Biofertilizer, $F_{5}=$ Organic fertilizer and $F_{6}=$ Combination.

Effect of fertilizers

The data in Table 3 indicated that seed weight/ plant and most of its components, i.e., number of pods/plant, 100-seed weight and seed weight/ pod were significantly affected by the tested fertilizer treatments in both seasons. However, the differences among tested fertilizer treatments were not great enough to reach the $5 \%$ level of significance in both seasons. Moreover, it can be noted that the application of biofertilizer treatment $\left(\mathrm{F}_{4}\right)$ was most effective for increasing seed weight/ plant and its components. As an average of the two seasons, the increase percentage due to the application of $\mathrm{F}_{4}$ amounted to $119.44 \%, 35.67 \%$ , $25.89 \%$ and $215.95 \%$ for no. of pods/plant, 100 - seed weight, seed weight/pod and seed weight/ plant, respectively more than unfertilized plants $\left(F_{1}\right)$. The evident enhancement in these treatments owing to the application of $\mathrm{F}_{4}$ treatment may be due to the compatibility structure of such tested biofertilizer which included some useful bacteria, i.e., NFB, PSB and KMB as well as some beneficial fungus, i.e., yeast and Trichoderma. Such bacteria may be had enhancing effect on plant growth and productivity through their ability to release some promoters phytohormone such as indole acetic acid, ethylene, gibberllins acid and cytokinins as well as increase essential nutrients supply (N , P and K) for plant growth (Gupta et al., 2015). In addition, the yeast extract 
considered one of the richest sources of essential amino acids, minerals, B-complex vitamins and some promoters hormones (Mahmoud et al., 2013) as well as Trichoderma which had effective antagonists against soil-born plant pathogenic fungi (Rudresh et al., 2005). The combining of those different organisms may be caused a great potential and beneficial effect on the growth and productivity of plants.

TABLE 3. Effect of mineral, organic and bio-fertilizers on seed weight/plant and its components as well as translocation indices of two chickpea cultivars (at harvest) during 2015/2016 and 2016/2017 seasons.

\begin{tabular}{|c|c|c|c|c|c|c|c|c|c|c|}
\hline \multirow{2}{*}{ Treatments } & \multicolumn{2}{|c|}{$\begin{array}{l}\text { Number of } \\
\text { pods/plant }\end{array}$} & \multicolumn{2}{|c|}{$\begin{array}{l}\text { Number of } \\
\text { seeds/pod }\end{array}$} & \multicolumn{2}{|c|}{$\begin{array}{l}\text { 100-seed weight } \\
\text { (g) }\end{array}$} & \multicolumn{2}{|c|}{$\begin{array}{c}\text { Seed weight/pod } \\
\text { (g) }\end{array}$} & \multicolumn{2}{|c|}{$\begin{array}{l}\text { Seed weight/ } \\
\text { plant (g) }\end{array}$} \\
\hline & S1 & S2 & S1 & S2 & S1 & S1 & S1 & S2 & S1 & S2 \\
\hline \multicolumn{11}{|c|}{ Cultivars (C) } \\
\hline Giza 3 & $28.26^{\mathrm{b}}$ & $32.65^{\mathrm{b}}$ & $1.20^{\mathrm{a}}$ & $1.26^{\mathrm{a}}$ & $11.66^{\mathrm{b}}$ & $14.72^{\mathrm{b}}$ & $0.167^{\mathrm{b}}$ & $0.179^{\mathrm{b}}$ & $5.14^{\mathrm{b}}$ & $5.89^{\mathrm{b}}$ \\
\hline Giza 195 & $58.80^{\mathrm{a}}$ & $59.27^{\mathrm{a}}$ & $1.44^{\mathrm{a}}$ & $1.48^{\mathrm{a}}$ & $16.23^{\mathrm{a}}$ & $17.96^{\mathrm{a}}$ & $0.223^{\mathrm{a}}$ & $0.242^{\mathrm{a}}$ & $12.82^{\mathrm{a}}$ & $13.88^{\mathrm{a}}$ \\
\hline $\mathrm{LSD}_{0.05}$ & 8.34 & 7.06 & Ns & Ns & 3.01 & 0.40 & 0.035 & 0.039 & 1.68 & 1.62 \\
\hline \multicolumn{11}{|c|}{ Fertilizers (F) } \\
\hline $\mathrm{F}_{1}$ & $26.72^{\mathrm{e}}$ & $28.33^{\mathrm{d}}$ & $1.17^{\mathrm{a}}$ & $1.20^{\mathrm{a}}$ & $11.53^{\mathrm{c}}$ & $13.05^{\mathrm{c}}$ & $0.181^{\mathrm{b}}$ & $0.176^{\mathrm{b}}$ & $4.72^{\mathrm{d}}$ & $4.74^{\mathrm{d}}$ \\
\hline $\mathrm{F}_{2}$ & $48.04^{\mathrm{b}}$ & $45.69^{\mathrm{b}}$ & $1.32^{\mathrm{a}}$ & $1.32^{\mathrm{a}}$ & $13.56^{\mathrm{b}}$ & $16.73^{\mathrm{b}}$ & $0.200^{\mathrm{ab}}$ & $0.204^{\mathrm{ab}}$ & $8.48^{\mathrm{c}}$ & $8.71^{\mathrm{c}}$ \\
\hline $\mathrm{F}_{3}$ & $40.94^{c}$ & $43.50^{b}$ & $1.30^{\mathrm{a}}$ & $1.32^{\mathrm{a}}$ & $14.72^{\mathrm{ab}}$ & $16.59^{b}$ & $0.191^{\mathrm{ab}}$ & $0.202^{\mathrm{ab}}$ & $8.13^{c}$ & $9.09^{c}$ \\
\hline $\mathrm{F}_{4}$ & $60.53^{\mathrm{a}}$ & $60.16^{\mathrm{a}}$ & $1.37^{\mathrm{a}}$ & $1.48^{\mathrm{a}}$ & $15.17^{\mathrm{a}}$ & $18.24^{\mathrm{a}}$ & $0.212^{\mathrm{a}}$ & $0.237^{\mathrm{a}}$ & $14.72^{\mathrm{a}}$ & $15.17^{\mathrm{a}}$ \\
\hline $\mathrm{F}_{5}$ & $32.97^{\mathrm{d}}$ & $38.52^{c}$ & $1.35^{\mathrm{a}}$ & $1.38^{\mathrm{a}}$ & $14.71^{\mathrm{ab}}$ & $16.35^{\mathrm{b}}$ & $0.197^{\mathrm{ab}}$ & $0.220^{\mathrm{ab}}$ & $7.22^{\mathrm{c}}$ & $8.44^{\mathrm{c}}$ \\
\hline $\mathrm{F}_{6}$ & $51.98^{\mathrm{b}}$ & $59.60^{\mathrm{a}}$ & $1.43^{\mathrm{a}}$ & $1.53^{\mathrm{a}}$ & $13.97^{\mathrm{ab}}$ & $17.09^{\mathrm{b}}$ & $0.187^{b}$ & $0.223^{\mathrm{ab}}$ & $10.61^{\mathrm{b}}$ & $13.16^{\mathrm{b}}$ \\
\hline $\operatorname{LSD}_{0.05}$ & 5.04 & 3.02 & Ns & Ns & 1.38 & 0.98 & 0.025 & 0.049 & 1.79 & 1.34 \\
\hline Interaction $(\mathrm{C} \times \mathrm{F})$ & $* *$ & $* *$ & ns & ns & ns & ns & ns & ns & $* *$ & $* *$ \\
\hline
\end{tabular}

$\mathrm{S} 1=$ First season; $\mathrm{S} 2=$ Second season; $\mathrm{LSD}=$ Least significant difference; $*=\mathrm{P} \leq 0.05 ; * *=\mathrm{P} \leq 0.01 ; \mathrm{Ns}=$ non-significant

$\mathrm{F}_{1}=$ Control, $\mathrm{F}_{2}=$ Macro elements, $\mathrm{F}_{3}=$ Micro elements, $\mathrm{F}_{4}=$ Biofertilizer, $\mathrm{F}_{5}=$ Organic fertilizer, $\mathrm{F}_{6}=$ Combination.

TABLE 4. Effect of mineral, organic and bio-fertilizers on seed, straw and biological yields/ha as well as translocation indices of two chickpea cultivars (at harvest) during 2015/2016 and 2016/2017 seasons.

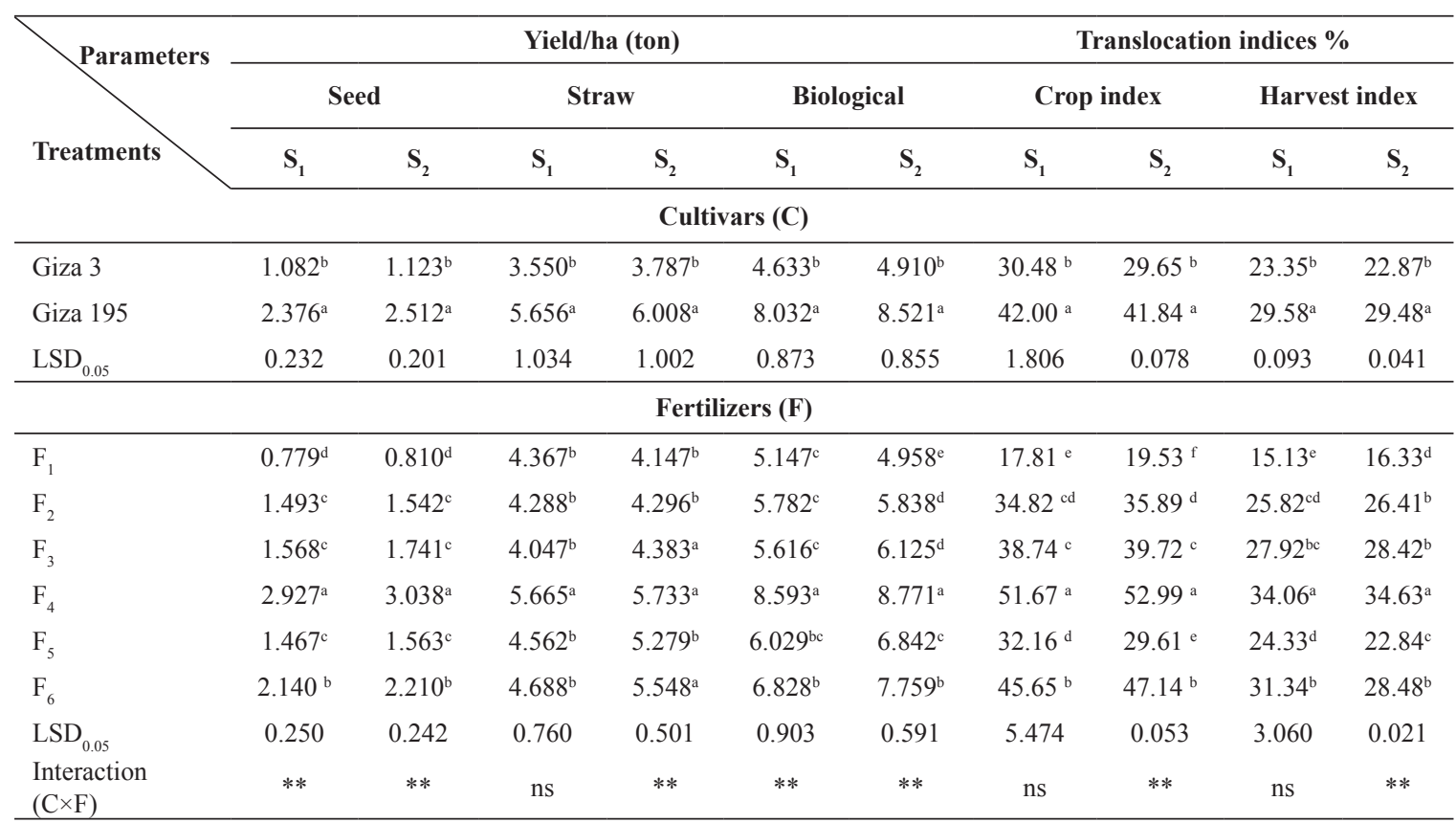

$\mathrm{S} 1=$ First season; $\mathrm{S} 2=$ Second season; $\mathrm{LSD}=$ Least significant difference; $*=\mathrm{P} \leq 0.05 ; * *=\mathrm{P} \leq 0.01 ; \mathrm{Ns}=$ non-significant

$\mathrm{F}_{1}=$ Control, $\mathrm{F}_{2}=$ Macro elements, $\mathrm{F}_{3}=$ Micro elements, $\mathrm{F}_{4}=$ Biofertilizer, $\mathrm{F}_{5}=$ Organic fertilizer, $\mathrm{F}_{6}=$ Combination 
The data presented in Table 4 revealed that seed, straw and biological yields/ha were beneficially responded to the application of macro elements $\left(\mathrm{F}_{2}\right)$, micro elements $\left(\mathrm{F}_{3}\right)$, biofertilizer $\left(\mathrm{F}_{4}\right)$ and organic fertilizers $\left(\mathrm{F}_{5}\right)$ as well as their combination $\left(\mathrm{F}_{6}\right)$ compared to the unfertilized plants $\left(F_{1}\right)$ in the two seasons. In comparison among the tested fertilizers, it can be observed that the application of biofertilizer treatment $\left(\mathrm{F}_{4}\right)$ recorded the highest significant values for seed, straw and biological yields/ha which were increased by $275.40 \%, 33.98 \%$ and $71.93 \%$ more than the control treatment $\left(\mathrm{F}_{1}\right)$, respectively as an average of the two seasons. Moreover, the combined application of all tested fertilizers $\left(\mathrm{F}_{6}\right)$ took the second rank for seed, straw and biological yields/ha compared to the rest treatments in both seasons. From these results, it can be suggested that the increase of growth characters (Table 2) as well as seed weight/plant and its components (Table 3 ) due to the application of combination treatment $\left(\mathrm{F}_{6}\right)$ and biofertilizer $\left(\mathrm{F}_{4}\right)$ eventually contributed to higher seed, straw and biological yields/ha. In this concern, Kumar et al (2014) found that the application of different biofertilizers like Rhizobium and PSB as well as mycorrhiza fungi exhibited positive influence on seed and stover yields of chickpea. Moreover, other researchers found positive response of chickpea productivity to the application of some macronutrients, i.e., N (Yagmur \& Kaydan, 2011 and Namvar et al., 2013), P (Dutta \& Bandyopadhyay, 2009 and Lusiba et al., 2018) and K (Ahmed et al., 2015), micronutrients, i.e., Fe (Janmohammadi et al., 2012) and B (Alam et al., 2017) and some beneficial bacteria, i.e., NFB (Rokhzadi \&Toashih, 2011), PSB (Kumar et al., 2014) as well as some fungu, i.e., yeast (Ahmed et al., 2010) and Trichoderma (Mohammadi et al., 2011).

Concerning the translocation indices, i.e., crop and harvest indices, the data in Table 4 show that the values of the two traits were significantly affected by the tested fertilizer treatments in both season. The highest significant values of crop index (52.33\%) and harvest index (34.34\%) were achieved when chickpea plants were treated with biofertilizer treatment $\left(\mathrm{F}_{4}\right)$, while the lowest significant values, i.e., $18.67 \%$ and $15.73 \%$ for the same respective traits were obtained by the unfertilized plants $\left(\mathrm{F}_{1}\right)$ as an average of the two season. From these results, it can be suggested that tested biofertilizer treatment had a greater efficiency to translocate the amount of photosynthetic material from the vegetative plant parts to the developing seeds more than the other tested fertilizers treatments.

\section{Effect of the interaction between cultivars and fertilizers}

The interaction effect between the two chickpea cultivars and fertilizer treatments was statistically significant for number of pods and seed weight/ plant as well as seed and biological yields/ha (Fig. 2 ) in the two seasons. In comparison among the tested interactiontreatments, the data showed that Giza 195 cultivar significantly surpassed Giza 3 cultivar under either any experienced fertilizer or control treatment in both seasons. Moreover, it can be noted that Giza 195 cultivar treated with biofertilizer $\left(\mathrm{F}_{4}\right)$ produced the highest values of number of pods (88.40 and 84.23), seed weight/ plant $(21.99$ and $22.01 \mathrm{~g})$, seed yield/ha (4.003 and 4.093 ton/ha) and biological yield/ha ( 11.251 and $11.597 \mathrm{ton} / \mathrm{ha}$ ) in the first and second season, respectively. In addition, the interaction treatment of Giza 195 cultivar with combination treatment $\left(\mathrm{F}_{6}\right)$ took the second rank for the abovementioned traits in both seasons. On the contrary, the lowest values for such traits were obtained when Giza 195 and Giza 3 cultivars were untreated with any fertilizers (control treatment, $\mathrm{F}_{1}$ ) in a descending order. From these results, it can be concluded that the application of tested biofertilizer $\left(\mathrm{F}_{4}\right)$ is necessary for increasing the yielding ability of Giza 195 cultivar in this experiment.

\section{Seed quality \\ Varietal differences}

Data represented in Table 5 indicated that there were significant differences between the two chickpea cultivars in seed quality, i.e., nitrogen , crude protein, carbohydrate, fiber and ash percentages in both seasons. Moreover, it can be observed that Giza 195 cultivar surpassed Giza 3 cultivar in each of nitrogen, crude protein and carbohydrate percentages in both seasons. The superiority of Giza 195 cultivar in such seed quality characters may be due to the increase in its dry matter accumulation (Table 2), weight of seeds (Table 3 ) and metabolites translocation (Table 4). On the contrary, the data indicated that Giza 3 cultivar was superior to Giza 195 cultivar in fiber and ash percentages in the two seasons. In this concern, other investigators found variations among chickpea varieties in protein and carbohydrate content (Xu et al., 2013 and Aguilar-Raymundo \& Velez-Ruiz, 2016 ) as well as fiber and ash contents (Sharma et al., 2013 and 
Tessema et al., 2015 ). From these results, it can be concluded that Giza 195 chickpea cultivar is a good source of nitrogen, crude protein and carbohydrate percentages but is limited in fiber and ash percentages.

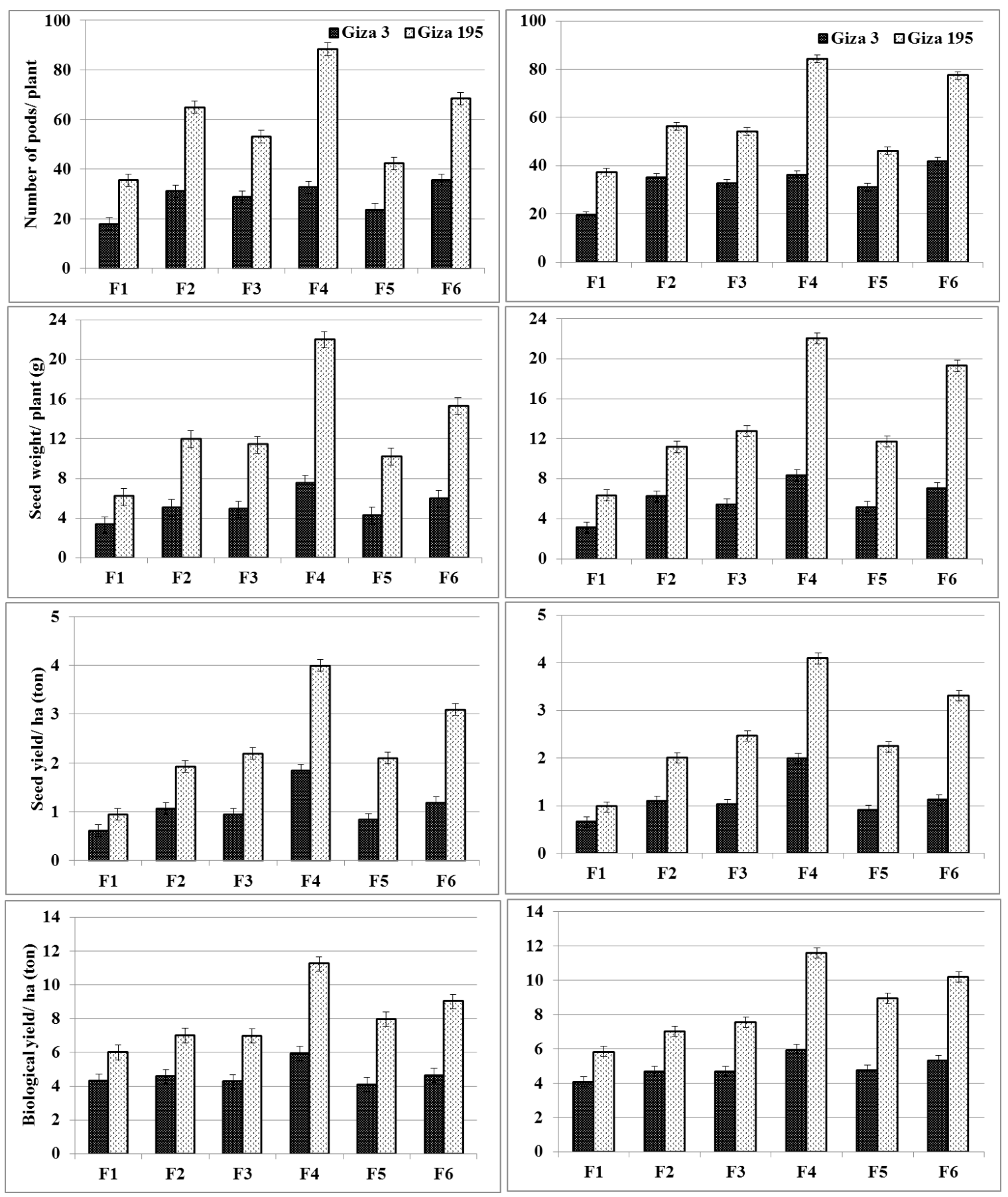

Fig. 2. Effect of the interaction between chickpea cultivars and fertilizer treatments on number of pods/plant, seed weight/plant and seed and biological yield/ha during 2015/2016 and 2016/2017 seasons.

$F_{1}=$ Control, $F_{2}=$ Macro elements, $F_{3}=$ Micro elements, $F_{4}=$ Biofertilizer, $F_{5}=$ Organic fertilizer and $F_{6}=$ Combination. 
TABLE 5. Effect of mineral, organic and bio-fertilizers on seed quality of two chickpea cultivars (at harvest) during 2015/2016 and 2016/2017 seasons.

\begin{tabular}{|c|c|c|c|c|c|c|c|c|c|c|}
\hline \multirow{2}{*}{ Parameters } & \multicolumn{2}{|c|}{ Nitrogen (\%) } & \multicolumn{2}{|c|}{$\begin{array}{c}\text { Crude protein } \\
(\%)\end{array}$} & \multicolumn{2}{|c|}{$\begin{array}{c}\text { Carbohydrate } \\
(\%)\end{array}$} & \multicolumn{2}{|c|}{ Fiber $(\%)$} & \multicolumn{2}{|c|}{ Ash (\%) } \\
\hline & $S_{1}$ & $\mathrm{~S}_{2}$ & $S_{1}$ & $\mathrm{~S}_{2}$ & $\mathrm{~S}_{1}$ & $\mathrm{~S}_{2}$ & $\mathrm{~S}_{1}$ & $\mathrm{~S}_{2}$ & $S_{1}$ & $\mathrm{~S}_{2}$ \\
\hline \multicolumn{11}{|c|}{ Cultivars (C) } \\
\hline Giza 3 & $3.17^{\mathrm{b}}$ & $3.13^{\mathrm{b}}$ & $19.84^{b}$ & $19.54^{b}$ & $60.80^{\mathrm{b}}$ & $60.85^{\mathrm{b}}$ & $3.53^{\mathrm{a}}$ & $3.54^{\mathrm{a}}$ & $3.03^{\mathrm{a}}$ & $3.02^{\mathrm{a}}$ \\
\hline Giza 195 & $3.51^{\mathrm{a}}$ & $3.44^{\mathrm{a}}$ & $21.94^{\mathrm{a}}$ & $21.48^{\mathrm{a}}$ & $61.87^{\mathrm{a}}$ & $62.15^{\mathrm{a}}$ & $3.47^{\mathrm{b}}$ & $3.48^{\mathrm{b}}$ & $2.96^{\mathrm{b}}$ & $2.97^{b}$ \\
\hline $\mathrm{LSD}_{0.05}$ & 0.16 & 0.13 & 1.01 & 0.84 & 0.56 & 0.58 & 0.02 & 0.05 & 0.02 & 0.03 \\
\hline \multicolumn{11}{|c|}{ Fertilizers (F) } \\
\hline $\mathrm{F}_{1}$ & $2.87^{\mathrm{c}}$ & $2.79^{c}$ & $17.97^{\mathrm{c}}$ & $17.49^{c}$ & $57.56^{\mathrm{c}}$ & $58.04^{\mathrm{d}}$ & $3.34^{\mathrm{d}}$ & $3.35^{\mathrm{d}}$ & $2.93^{\mathrm{d}}$ & $2.94^{\mathrm{d}}$ \\
\hline $\mathrm{F}_{2}$ & $3.31^{\mathrm{b}}$ & $3.33^{\mathrm{b}}$ & $20.74^{\mathrm{b}}$ & $20.86^{\mathrm{b}}$ & $60.90^{\mathrm{b}}$ & $61.49^{\mathrm{b}}$ & $3.54^{\mathrm{c}}$ & $3.53^{\mathrm{c}}$ & $3.15^{\mathrm{b}}$ & $3.16^{\mathrm{b}}$ \\
\hline $\mathrm{F}_{3}$ & $3.22^{\mathrm{b}}$ & $3.23^{\mathrm{b}}$ & $20.18^{b}$ & $20.23^{b}$ & $60.97^{b}$ & $61.06^{\mathrm{b}}$ & $3.66^{\mathrm{b}}$ & $3.65^{\mathrm{b}}$ & $3.02^{\mathrm{c}}$ & $3.00^{\mathrm{c}}$ \\
\hline $\mathrm{F}_{4}$ & $3.66^{\mathrm{a}}$ & $3.49^{\mathrm{a}}$ & $22.88^{\mathrm{a}}$ & $21.82^{\mathrm{a}}$ & $64.56^{\mathrm{a}}$ & $63.73^{\mathrm{a}}$ & $3.34^{\mathrm{d}}$ & $3.35^{\mathrm{d}}$ & $2.82^{\mathrm{e}}$ & $2.83^{\mathrm{e}}$ \\
\hline $\mathrm{F}_{5}$ & $3.31^{\mathrm{b}}$ & $3.24^{\mathrm{b}}$ & $20.70^{\mathrm{b}}$ & $20.25^{\mathrm{b}}$ & $60.32^{\mathrm{b}}$ & $60.20^{\mathrm{c}}$ & $3.78^{\mathrm{a}}$ & $3.79^{\mathrm{a}}$ & $3.25^{\mathrm{a}}$ & $3.23^{\mathrm{a}}$ \\
\hline $\mathrm{F}_{6}$ & $3.76^{\mathrm{a}}$ & $3.58^{\mathrm{a}}$ & $23.53^{\mathrm{a}}$ & $22.41^{\mathrm{a}}$ & $64.70^{\mathrm{a}}$ & $64.48^{\mathrm{a}}$ & $3.36^{\mathrm{d}}$ & $3.38^{\mathrm{d}}$ & $2.85^{\mathrm{e}}$ & $2.83^{\mathrm{e}}$ \\
\hline $\mathrm{LSD}_{0.05}$ & 0.11 & 0.12 & 0.72 & 0.79 & 0.93 & 0.77 & 0.07 & 0.04 & 0.04 & 0.03 \\
\hline $\begin{array}{l}\text { Interaction } \\
(\mathrm{C} \times \mathrm{F})\end{array}$ & $*$ & ns & * & ns & ns & $*$ & ns & $*$ & ns & $*$ \\
\hline
\end{tabular}

$\mathrm{S} 1=$ First season; $\mathrm{S} 2=$ Second season; $\mathrm{LSD}=$ Least significant difference; $*=\mathrm{P} \leq 0.05 ; * *=\mathrm{P} \leq 0.01 ; \mathrm{Ns}=$ non-significant

$\mathrm{F}_{1}=$ Control, $\mathrm{F}_{2}=$ Macro elements, $\mathrm{F}_{3}=$ Micro elements, $\mathrm{F}_{4}=$ Biofertilizer, $\mathrm{F}_{5}=$ Organic fertilizer, $\mathrm{F}_{6}=$ Combination.

\section{Effect of fertilizers}

Data in Table 5 indicated that the different seed quality, i.e., nitrogen, crude protein, carbohydrate, fiber and ash percentages in chickpea seeds were significantly and positively responded to the tested fertilizers as compared to the unfertilized plants (control treatment) in both seasons. Moreover, the results showed that the combination treatment $\left(\mathrm{F}_{6}\right)$, i.e., macro and micronutrients + biofertilizer and organic fertilizers caused the maximum significant values of nitrogen $\%(3.67 \%)$, protein $\%(22.97 \%)$ and carbohydrate \% (64.59\%), as an average of both seasons without significant differences with those obtained by the biofertilizer treatment $\left(\mathrm{F}_{4}\right)$ in the two seasons. From these results, it can be concluded that the pronounced increase in these traits obtained by the application of $\mathrm{F}_{6}$ treatment may be due to that such treatment included some macro and micro elements as well as bio and organic fertilizers which led to increase the mineral availability uptake in the plants and consequently in seeds. In this concern, many researchers found the protein percentage in chickpea seeds was increased by the application of NPK elements (Goud et al., 2014 and Shah et al., 2016), Fe element (El-Habbasha et al., 2012), biofertilizers, i.e., NFB + PSB (Kumar et al., 2014) and Trichoderma fungi (Mohammadi et al., 2011). Moreover, other investigators found that the carbohydrate percentage in chickpea seeds was also increased by the application of mineral fertilizers included $\mathrm{K}$ element (Ahmed et al., 2015) as well as Fe, Mn and B elements (El-Habbasha et al., 2012). On the other hand, fiber and ash percentages were found to be significantly enhanced by the application of humic acid compared to the other tested fertilizers and control treatment in both seasons. In this concern, Fouda (2017) found that the application of humic acid caused an increase in each of fiber and ash percentages in the seeds of faba bean compared to untreated plants.

Effect of the interaction between cultivars and fertilizers

The data of all seed quality studied herein in chickpea seeds were not significantly affected by the various tested fertilizer treatments in the first and/or the second seasons showing independence in their effect in this respect. Consequently, the data were excluded.

\section{Conclusion}

Bio-fertilizer as a single application should be encouraged for the productivity of chickpea (cv. Giza 195), since it improved its growth, yield and seed quality as well as can lessen the amount of mineral fertilizer and consequently the environmental pollution. 


\section{References}

Aguilar-Raymundo, V.G. and Vélez-Ruíz, J.F. (2016) Characterization of two chickpea varieties and the effect of cooking on their physico-chemical and functional properties of flours. Journal of Food Research, 5(5), 67-76.

A.O.A.C. (2000) "Official Methods of Analysis" of the Association of Official Analytical Chemist. $17^{\text {th }} \mathrm{ed}$. Washington, DC, USA.

Ahmed, Amal G., Ahmed, M.A., Hassanein, M.S. and Zaki, Nabila M. (2010) Effect of organic and biofertilization on growth and yield of two chickpea cultivars in newly cultivated land. J. Appl. Sci. Res. 6(12), 2000-2009.

Ahmed, Amal G., Mohamed, Magda H., Hassanein, M.S., Zaki, Nabila M., El Habbasha, S.F., Tawifk, M.M. and Mohamed, Manal F. (2015) Effect of water regime and potassium fertilization on productivity of two chickpea (Cicer arietinum L.) cultivars. Int. J. Chem.Tech, Res. 8(4), 1509-1519.

Alam, M.S., Ali, K.J. and Hoque, A. (2017) Yield and yield component of chickpea as affected by boron application. Journal of Experimental Agriculture International, 15(2), 1-9.

Aliu, S., Kaul, H.P., Rusinovci, I., Shala-Mayrhofer, V., Fetahu, S. and Zeka,. D. (2016) Genetic diversity for some nutritive traits of chickpea (Cicer arietinum L.) from different regions in Kosova. Turk J. of Field Crops, 21(1), 156-161.

Burnell, J.N. (1988) The biochemistry of manganese in plants. In: "Manganese in Soils and Plants", Graham, R.D., R.J. Hannam and N.C. Uren (Ed.). Kluwer Academic Publisher, Oordracht, pp. 125-137.

Chapman, H.D. and Pratt, P.F. (1978) "Methods of Analysis for Soils, Plants and Waters". Univ. California Div. Agric. Sci. Priced Publication, Oakland.

Dixit, C.K. and Yamdagni, R. (1983) Effect of zinc and iron on the chlorosis of mandarin. Guajarat Agr. Univ. Res. Jour. 8, 67-73.

Dutta, D. and Bandyopadhyay, P. (2009) Performance of chickpea (Cicer arietinum L.) to application of phosphorus and bio-fertilizer in laterite soil. Archives of Agronomy and Soil Science, 55(2), 147-155.

El-Habbasha, S.F., Ahmed, Amal G. and Mohamed, Magda H. (2012) Response of some chickpea varieties to compound foliar fertilizer under sandy soil conditions. J. Appl. Sci. Res. 8(10), 5177-5183.

Erman, M., Demir, S., Ocak, E., Tufenkci, S., Oguz, F. and Akkopru, A. (2011) Effects of Rhizobium, arbuscular mycorrhiza and whey applications on some properties in chickpea (Cicer arietinum L.) under irrigated and rainfed conditions 1-Yield, yield components, nodulation and AMF colonization. Field Crops Research, 122(1), 14-24.

FAOSTAT (2014) Food and agriculture organization of the United Nations Statistics Division. Available at: http://faostat.fao.org/site/567/DesktopDefault. aspx. (Accessed 10 January 2018).

Fouda, K.F. (2017) Effect of phosphorus level and some growth regulators on productivity of faba bean (Vicia faba L.). Egypt. J. Soil Sci. 57(1), 73-87.

Goud, V.V., Konde, N.M., Mohod, P.V. and Kharche, V.K. (2014) Response of chickpea to potassium fertilization on yield, quality, soil fertility and economic in vertisols. Legume Res. 37(3), 311-315.

Gupta, G., Parihar, S.S., Ahirwar, N.K., Snehi, S.K. and Singh, V. (2015) Plant growth promoting rhizobacteria (PGPR): Current and future prospects for development of sustainable agriculture. Journal of Microbial \& Biochemical Technology, 7(2), 96-102.

Jackson, M.L.(1973) "Soil Chemical Analysis" Prentice Hall of India Pvt. Ltd., New Delhi; p. 498.

Janmohammadi, M., Javanmard, A. and Sabaghnia, N. (2012) Influences of micro-nutrients (zinc and iron) and bio-fertilizer on yield and yield components of chickpea (Cicer arietinum L.) cultivars. Agriculture \& Forestry, 57(3), 53-66.

Jukanti, A.K., Gaur, P.M., Gowda, C.L.L. and Chibbar, R.N. (2012) Nutritional quality and health benefits of chickpea (Cicer arietinum L.): A review. $\mathrm{Br}$. $J$. Nutr. 108, 11-26.

Kumar, D., Arvadiya, L.K., Kumawat, A.K., Desai, K.L. and Patel, T.U. (2014) Yield, protein content, nutrient cntent and uptake of chickpea (Cicer arietinum L.) as influenced by graded levels of fertilizers and bio-fertilizers. Res. J. Chem. Environ. Sci. 2(6), 60-64.

López-Millán, A.F., Ellis, D.R. and Grusak, M.A. (2004) Identification and characterization of several new members of the ZIP family of metal transporters in Medicago truncatula. Plant Mol. Biol. 54, 583-596.

Lusiba, S., Odhiambo, J. and Ogola, J. (2018) Growth, yield and water use efficiency of chickpea (Cicer arietinum): Response to biochar and phosphorus fertilizer application. Archives of Agronomy and Soil Science, 64(6), 819-833.

Magdi, T.A., Selim, E.M. and El-ghamry, A.M. (2011) Integrated effects of bio and mineral fertilizers and humic substances on growth yield and nutrient contents of fertigated cowpea (Vigna unguiculata L.). Journal of Agronomy, 10(1), 34-39.

Mahmoud, Asmaa R., El-Desuki, M., Abdel-Mouty, Mona M. and Ali, Aisha H. (2013) Effect of 
compost levels and yeast extract application on the pea plant growth, pod yield and quality. J. Appl. Sci. Res. 9(1), 149-155.

Marschner, H. (1995) "Mineral Nutrition of Higher Plants". Academic Press, London.

Mohammadi, K., Ghalavand, A., Aghaalikhani, M., Heidari, G. and Sohrabi, Y. (2011) Introducing sustainable soil fertility system for chickpea (Cicer arietinum L.). Afr. J. Biotechnol. Res. 10(32), 6011-6020.

Namvar, A., Sharifi, R.S., Khandan, T. and Moghadam, M.J. (2013) Seed inoculation and inorganic nitrogen fertilization effects on some physiological and agronomical traits of chickpea (Cicer arietinum L.) in irrigated condition. Journal of Central European Agriculture, 14(3), 881-893.

Namvar, A., Seyed, R., Sedghi, M., Asghari, R., Khandan, T. and Eskandarpour, B. (2011) Study on the effects of organic and inorganic nitrogen fertilizer on yield, yield components and nodulation state of chickpea (Cicer arietinum L.). Communications in Soil Science and Plant Analysis, 42(9), 1097-1109.

Rokhzadi, A. and Toashih, V. (2011) Nutrient uptake and yield of chickpea (Cicer arietinum L.) inoculated with plant growth-promoting rhizobacteria. Australian Journal of Crop Science, 5(1), 44-48.

Rout, G.R. and Sahoo, S. (2015) Role of iron in plant growth and metabolism. Reviews in Agricultural Science, 3, 1-24.

Rudresh, D.L., Shivaprakash, M.K. and Prasad, R.D. (2005) Effect of combined application of Rhizobium, phosphate solubilizing bacterium and Trichoderma spp. on growth, nutrient uptake and yield of chickpea (Cicer arietinum L.). Applied Soil Ecology, 28, 139-146.

Shah, T., Fareed, A. and Nauman, M. (2016) Yield and quality response of chickpea cultivars to different NPK levels. Austin Food Sci. 1(4), 1-4.

Sharif, M., Khattak, R.A. and Sarir, M.S. (2003) Residual effect of humic acid and chemical fertilizers on maize yield and nutrient accumulation. Sarhad Journal of Agriculture, 19, 543-550.
Sharma, S., Yadav, N., Singh, A. and Kumar, R. (2013) Nutritional and antinutritional profile of newly developed chickpea (Cicer arietinum L.) varieties. International Food Research Journal, 20(2), 805-810.

Tecator, A.B. (1991) Determination of kjeldahl nitrogen content with Kjeltec Autosystem I, II, III and IV. Tecator Application Note An 30/81, Hogana, Sweden.

Tessema, K., Tadesse, F.T. and Kurabachew, H. (2015) Effects of different treatments for the control of Callosobruchus chinensis L. on proximate composition of chickpea (Cicer arietinum L.), in Meskan district, Ethiopia. J. Stored Prod. Postharvest Res. 6(10), 83-90.

Van Soest, P.J. and McQueen, R.W. (1973) The chemistry and estimation of fibre. Proc. Nutr. Soc. 32, 123-130

Vance, C.P. (1997) Enhanced agricultural sustainability through biological nitrogen fixation. In: Biological Fixation of Nitrogen for Ecology a Sustainable Agriculture, Legocki, A., Bothe, H., Pühler, A. (Ed.). Proc. NATO Adv. Res. Work, Ponzan, Poland, 10-14 September 1996. Springer-Verlag, Berlin, Germany, 179-185.

Wang, R., Gangola, M.P., Jaiswal, S., Gaur, P.M., Båga, M. and Chibbar, R.N. (2017) Genotype, environment and their interaction influence seed quality traits in chickpea (Cicer arietinum L.). Journal of Food Composition and Analysis, 63, 21-27.

Xu, Y., Sismour, E.N., Narina, S.S., Dean, D., Bhardwaj, H.L. and Li, Z. (2013) Composition and properties of starches from Virginia-grown kabuli chickpea (Cicer arietinum L.). International Journal of Food Science and Technology, 48, 539-547.

Yagmur, M. and Kaydan, D. (2011) Plant growth and protein ratio of spring sown chickpea with various combinations of Rhizobium inoculation, nitrogen fertilizer and irrigation under rainfed condition. Afr. J. Agric. Res. 6(12), 2648-2654. 


\section{تأثير التسميد العضوى والمعدني والحيوى على صفات النمو والمحصول والجودة لبعض اصناف الحمص السيد \\ محمود فتحى سليمان و محمد سبد عبدالعال

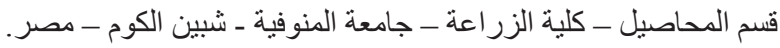

أجريت تجربتان حقليتان بمزرعة كلية الزراعة جامعة المنوفية بشبين الكوم، مصر خلال موسمي الزراعة

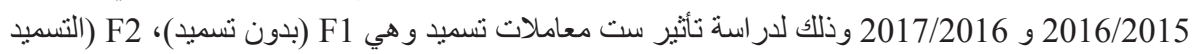

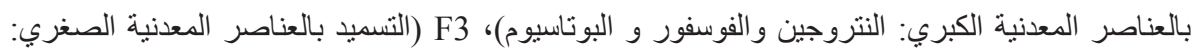

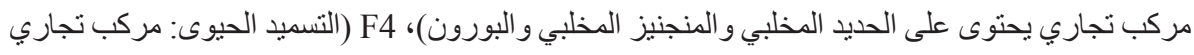

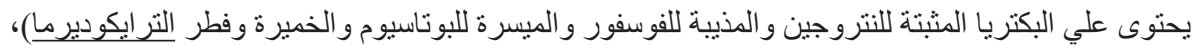

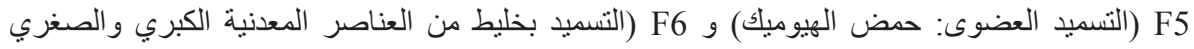

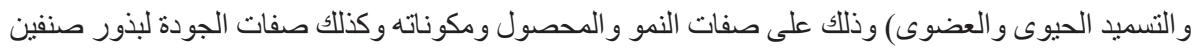
من محصول الحمص وهما جيزة 3 و جيزة 195 ويمكن ايجاز أهم النتائج المتحصل علئ وليها كالتالي:

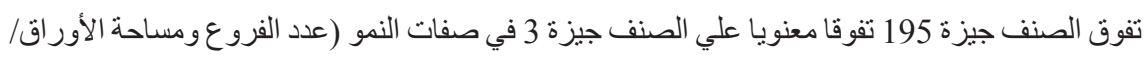

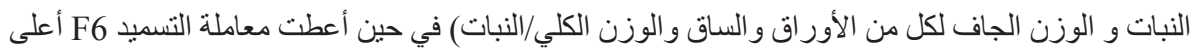

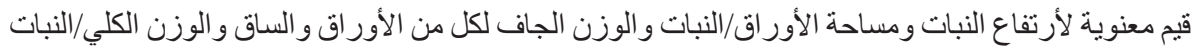

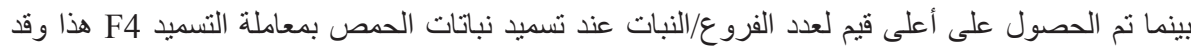

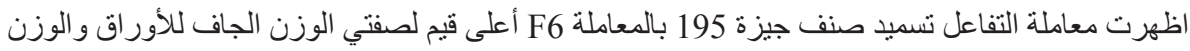
الكلي/النبات خلال موسمي الزرة اعة.

أظهر الصنف جيزة 195 تفوقا معنويا على صنف جيزة 3 في وزن البذور/النبات ومكوناته (عدد القرون/

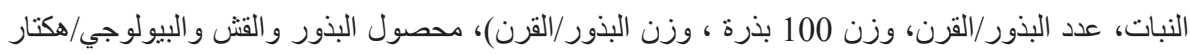

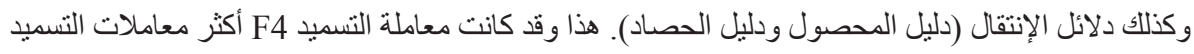

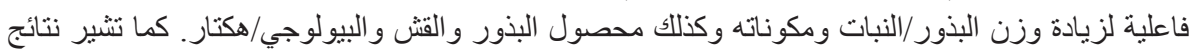

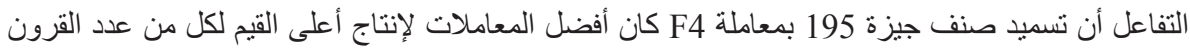
ووزن البذور/النبات ومحصول البذور و البيولوجي/هكتار في كلا الموسمين.

أظهرت نتائج الدراسة تفوق صنف جيزة 195 في صفات جودة البذور (النسبة المئوية لكل من النيتروجين

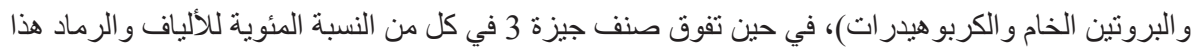

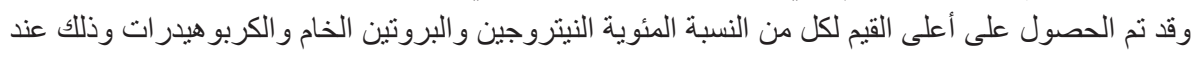

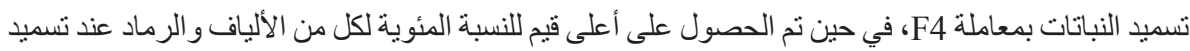
النباتات بالمعاملة F5 وذللك بالمقارنة بباقي معاملات التسميد المختبرة الأخرى. 